\title{
Venezuela's Orinoco Mining Arc: A literature review of Environmental Impacts
}

\author{
Doris Rivero*, Ying Liu** \\ * College of Environmental Science and Engineering, Tongji University
}

DOI: $10.29322 /$ IJSRP.10.02.2020.p9812

http://dx.doi.org/10.29322/IJSRP.10.02.2020.p9812

\begin{abstract}
The Bolivarian Republic of Venezuela is a country rich in metallic and non-metallic minerals. After the strategic importance of minerals in the world to provide the fundamental raw materials required in everyday life, this paper provides a review and synthesis of the literature about the environmental implications of the establishment of the Orinoco Mining Arc (OMA) National Strategic Development Zone, or by its name in Spanish Arco Minero del Orinoco (AMO), created by decree No. 2.248 in February 24th, 2016 to take advantage of the potential of mining activity as an alternative to oil rent, to exploit minerals in a surface covering $111.843,70$ square kilometers $(12,2 \%$ of the national territory). However, this area supports a great biological diversity and large water reserves and forestry, fragile and low resilience ecosystems to human intervention and is home to 55.000 indigenous people who belong to 22 ethnic groups. Many governments owned and foreigners companies have taken place for mineral exploitation in the region where economic development in the BR Venezuela has provoked social and environmental consequences, based on the debate is both a conflict of values and a dispute over the necessary basis for economic development.

The OMA multinational mining project has direct environmental implications on the ecosystems of the region, especially in the waters of the Amazon rivers and its extension, the Caroni basin, which provides one of the most important freshwater reserves in Venezuela; also everything that reaches the Orinoco River affects the water quality and species of the Caribbean Sea and the Atlantic Ocean. Venezuela's section of the Amazon rainforest would be at risk with the development of this project. Even with a robust legal framework of mining activity in the BR Venezuela, there is no evidence of the sustainable management policies related to this National Project. In this paper there is not consideration about theories of population environment linkages, neither the derived socio economic nor health issues. Even though OMA environmental impacts are discussed in most publications as being relevant for environment, there are few practical examples and quantitative data related to its direct implications. The study concludes that more primary studies of OMA environmental impacts are needed by the official Institutions in the BR Venezuela as well as governance initiatives to move ecological Mining concepts from theory to practice.
\end{abstract}

Index Terms- Mining, Orinoco Mining Arc, River Pollution, Extractivism, Alternatives to Extractivism, Amazon, Latin America, Conservation of Biodiversity, Environmental Rights, Artisanal/illegal extraction, Water management, National Parks, Forest Reserves.

\section{INTRODUCTION}

The Bolivarian Republic of Venezuela's economy during the last decades has been based on the exploitation of oil. Venezuela has $25,5 \%$ of the proven oil reserves worldwide, this is 302,81 billion barrels, which makes it the largest oil reserve in the world (OPEC, 2019). However, the supply of oil was affected after the year 2002 strike due to lack of the annual investments required in exploration and exploitation in the oil industry, in the middle of a severe social, political and economic crisis in the country. Venezuelan GDP presented a reduction since year 2015, from 560,89 million dollars to 315, 40 million dollars on 2018 (BCV, 2019).

On February 24th 2016, the National Executive published in Official Gazette No. 40,855, and Decree No. 2,248, the creation of the "National Strategic Development Zone Orinoco Mining Arc". The creation of this Strategic development zone is part of the Mining Engine, which is one of the fifteen engines that comprises the Bolivarian economic agenda in the way of the economic development of the Country, in the exploitation of the potential of the mineral resources that the country possesses as a key opportunity to contribute to the productive and social economic development of the nation, to emerge from the oil-rentier and achieve a diversified and integral productive system, following the fall in oil barrel prices and the decline of the oil production of Venezuela on 2015 (Martiz, 2019). Mining is an economic activity necessary to supply raw materials to the different Socio-productive chains of the country. Among the 
minerals present in the area are: gold, iron, diamond, and coltan, which exists only in seven countries of the world and is used in the manufacture of electronic devices such as cell phones, computers, satellites, televisions, and music players.

Under the regulation and control of the State, the OMA project seeks to bring some 135 companies from around the world to invest in a territory of over 111.843,70 square kilometers. (Km2) This "Strategic Development Zone," covers around 12\% of the national BR Venezuela territory. This Area is bigger than 19 American Countries and 17 European Countries (PROVEA, 2016). From a Regional description, this Zone occupies $46 \%$ of the Bolivar state, a large part of 10 of the 11 municipalities of the state, entity that concentrates the largest territorial proportion of the country, in contrast to one of the lowest population densities.

The area destined for this project covers tropical rainforests of the Venezuelan Amazon rainforest, the world's largest remaining tropical rainforest, furthermore, large extensions of fragile soils, an extraordinary biodiversity, and strategic sources of water, it is home to the largest water and forest reserves in the country: Venezuelan Guayana, which constitutes the upper reaches of the Guiana shield. In addition to the environmental implications on the delicate ecosystems of the region, the OMA project has large-scale effects from the socio-economic point of view for the inhabitants of the zone. Furthermore, Bolivar State has an enormous eco touristic potential, such a varied of national parks and natural monuments which represents a great stimulus to visit their places. The indigenous people of this region, who belong to the Caribe; Yanomami and Saliva tribe, will have to seriously alter their way of life and economic sustenance, where the mining operations proposed by the Decree go ahead.

The available literature, which has been synthesized within this paper, is primarily focused upon the great debates, controversies and confrontations generated by the creation of the OMA involving different actors and sectors of the national life. The analysis of environmental conflicts in Venezuela dates from 1980; the environmental aspect focuses on pointing out the consequences environmentally negative liberalized regimes adopted by the governments of the countries of Latin America and the Caribbean, as an indispensable measure to "competitively" insert themselves into the "global market". In the territory, there are long-standing conflicts, product of illegal mining, where trade unions, mafias, merchants, traffickers, irregular armed groups, military, and government officials control mining activity. Environmentalists, university experts, and Indigenous communities don't think that the proposal to regularize activities in the area by opening it to multinational mining corporations would drive illegal miners away. Furthermore, environmentalists denounce the lack of environmental impact assessment required by the current legal order for the development of this project.

Worldwide, mining is considered a cause of forest environmental destruction. Some of the impacts are direct, while others are indirect. Open pit mines completely transform the environment in the specific localities affected (Fearnside, 1990). Mining activity is rapidly increasing as an agent of environmental destruction in Amazonia. among its negative environmental impacts it is possible to quote; increased deforestation, loss of biodiversity, deterioration of water quality from surface runoff and river course, soil elimination and contamination, incorporation of pollutants, mainly heavy metals in the neighboring communities. This paper examines the literature about the Environmental implications of the OMA, without considering health; social, economic, political and cultural implications of the OMA. In this sense, literature is summarized from four scenarios: (i) OMA Institutional Framework; (ii) OMA legal Framework; (iii) OMA Environmental Impacts (iv) OMA Policies for Sustainable development.

\section{ORINOCO MINING ARC PROJECT AREA}

Venezuelan Guiana is the territory covered by the states of Amazonas, Bolívar and Delta Amacuro and covers an area of 458,345 km2 (Padilla, 2006). The Guiana Shield is a very old geological formation (Precambrian) that extends through 5 countries in the north of South America. In the BR Venezuela, it covers the region south of the Orinoco River (45\% of the national territory). The history and geological characteristics of this extension in the national territory have equally influenced the presence of a high diversity of mineral resources such as gold, diamond, iron and bauxite, Indigenous have boosted mining activity for centuries: gold and diOMAnd mining, has been developed more locally and handcrafted, while iron and bauxite mining has been developed on large and industrial scale (Explora, 2018). In general, the soils of Venezuelan Guiana are very poor in nutrients, due to the antiquity of the parental material and to repeated processes of washing, erosion, transport and deposition. Several authors (Lozada, 2017; Gold, 2003) explain that these characteristics generate fragility to ecosystems; some of them take many years in recovering its conditions naturally originals after a disturbance, or require restoration work to achieve some plant cover.

The Orinoco Mining Belt is located south of the Orinoco River, in the northern part of the Bolivar state, Bolivarian Republic of Venezuela. It has a total area of $111843.70 \mathrm{~km} 2$. According to the Ministry of People's Power for Ecological Mining Development, 
the activities of exploration and exploitation are being carried out in just 5\%, of that surface (MPPDME, 2018). According to this Ministry, once the exploration stage is completed, it is estimated that mineral exploitation will be carried out only in $1.5 \%$ of the Mining Arc.

It should be noted that the OMA is internally organized in four (4) areas for the purpose of development and administrative organization, and it is subdivided into smaller units according to the strategic minerals located in their subsoil. Gold, coltan, iron, and diamond are the most important of those minerals (Rosales, 2017). First Area named "Juana la Avanzadora" which surface area is 24,680.11 km2, located on the westernmost area, with the Cuchivero River as its eastern border, it mostly exploitation of Granite; Bauxite; Coltan, Rare Earth Minerals and diamond. Second Area named "Manuelita Saenz", which surface area is 17,246.16 km2; between the Cuchivero and Aro rivers, exploitation of Iron, Gold and diamond. Third Area named "Juana Hipolita", surface area is 29,730.37 km2; between the Aro river and the eastern limit of the Arco Minero, exploitation of iron; granite; quartz; bauxite and gold. Fourth Area "Josefa Camejo"; this area adds to the Arco Minero the Imataca Forest Reserve. Fourth Area surface area is 40,149.69 km2, mostly holds Gold; Bauxite; Copper; Kaolin and Dolomite.

The National government has placed more emphasis on Gold exploitation. According to the Minister of Petroleum and Mining and President of PDVSA, it is estimated that the gold reserves in the area would be 7,000 tons, which at current prices would represent about 280,000 million dollars. Regarding mineralized regions with primary gold, the area of El Callao occupies a preponderant place. This area has recently been designated as the most violent in Venezuela, with a homicide rate that in 2017 grew more than 800 percent over the previous year (Blanco \& Agudo, 2018). According to Rosales (2019), Las Cristinas and Las Brisas gold mines, located within the OMA, represent some of the most promising gold mines in Venezuela and in the whole of South America. Several authors (Lozada, 2017; Yerena, 2011) express this region has been the center of gold production since the Colonial era, in the 18th century (1842). In table one, Venezuela Mineral International legal certification is represented.

Table 1.

Venezuela Mineral International Legal Certification

\begin{tabular}{|l|r|r|}
\hline \multicolumn{1}{|c|}{ Mineral } & Ton & \multicolumn{1}{c|}{ Million $€$} \\
\hline Gold & 262.928 .472 & 94.000 \\
\hline Bauxite & 321.350 .000 & 14.000 \\
\hline Nickel & 28.927 .980 & 284.000 \\
\hline Iron & 14.678 .000 .000 & 717.000 \\
\hline Phosphate & 7.400 .000 & 666 \\
\hline Feldspar & 4.770 .629 & 281 \\
\hline \multicolumn{3}{|c|}{} \\
\hline Diamond & 1020 million carats \\
\hline
\end{tabular}

Source: Modified from: MPPDME (2018)

Figure 1

Orinoco Mining Arc Project site

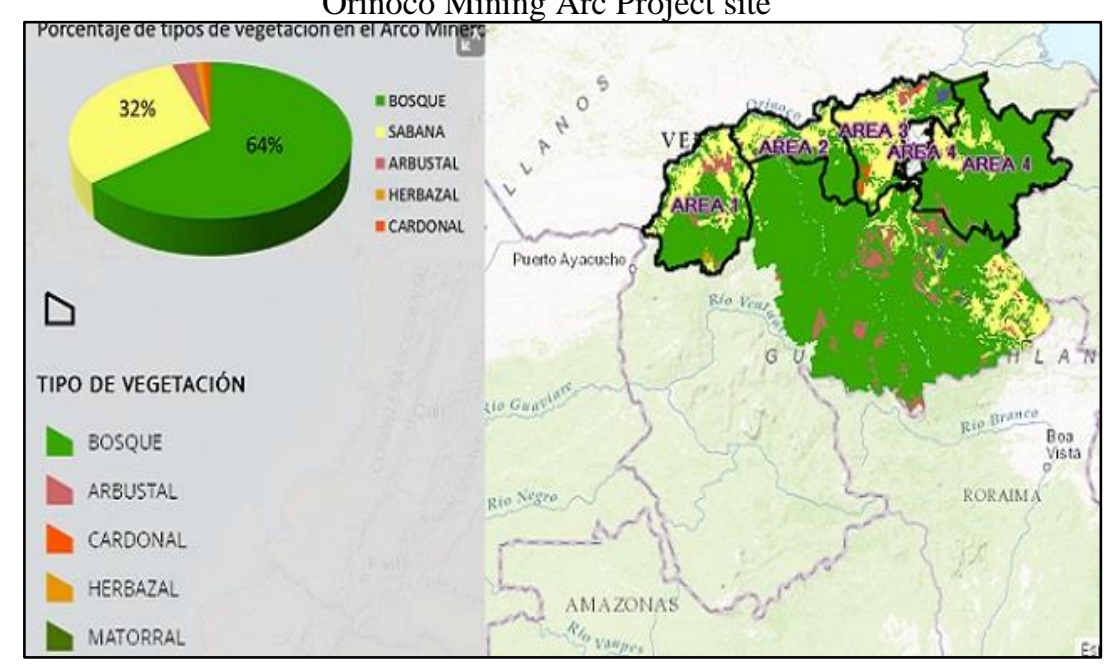

Source: Behm, (2016) 


\section{RESEARCH DATA AND FINDINGS}

Qualitative and Qualitative data were collected from online resources, an initial literature review was performed following the framework proposed by Odell, et al., (2018) capturing the main relationships of concern in the literature, getting the patterns that emerge from this review. This forms the foundation of a broader and more detailed analysis of existing academic and policy literature. Fortyfour (44) publications were sourced, including peer-reviewed articles, policy papers, scientific reports, official publications, research articles on scientific journals, university educational institutions and symposium declarations. Their content was synthesized using the thematic analysis method to address the raised issue. Four key themes were identified: (i) OMA Institutional Framework; (ii) OMA legal Framework; (iii) OMA Environmental Impacts (iv) OMA Policies for Sustainable development.

\section{(i) Orinoco Mining Arc Institutional Framework}

The Venezuelan mining industry is underdeveloped, if compares with the levels of industrialization of other Latin American countries. The mining legislation that governs and administers it is national for metallic minerals, and state (local) for most minerals non-metallic varying from state to state (Martiz, 2019). On year 2015, in Gazette $\mathrm{N}^{\circ}$ 40.634, of the Presidential Decree 1.701 Apr $7^{\text {th }}$, the Ministry of Environment and Natural Resources was eliminated, this produced reaction within diverse sectors of civil society asking to reverse the decree and warning of the consequences for the conservation of the environment, the climate and the sustainable management of the country natural resources (PROVEA, 2016). After this fact, Ministry of Eco socialism and Water (MINEA) was created. One year later, on June 9th, 2016, the Ministry of People's Power for Ecological Mining Development (In spanish MPPDME) was created by Presidential Decree No. 2350, published in the Official Gazette No. 40 922; in order to establish a governing entity on mining matters in Venezuela. which would work in parallel with the Ministry of Eco socialism and Waters (MINEA). About this Ministry, Lozada (2017) maintain that mining cannot be ecological because it can generate very serious environmental impacts that, although they may have control measures, prevent restitution of the ecosystem to its original condition, or the recovery of that state, would imply a span that exceeds of one generation.

Martiz, (2019) explains the role of the State and the Institutional framework and how the implementation of state, mixed and military companies has led to Mining Sector to a situation of disorder and confusion, unprecedented in the country. The Government has focused gold and diamond mining at the OMA in Small Mining or Artisanal Mining which estimating some 40,000 miners to execute it. With small miners operation, gold production has raised at 8.5 tons in 2017, as well as 2,000 carats of diamond and 9.1 tons of gold in 2018 first semester entering the Venezuela Central Bank. About the Small scale and illegal mining activities, Rosales (2019) explains the lack of institutional capacity to control it and long-term bias towards Artisanal scale mining (ASM) activities contribute to precarious work as well as unsafe and potentially exploitative conditions of irregular miners. Surface mining is the dominant method of mining used by small-scale mining artisans due to its cost effectiveness, low capital intensity and minimal technical skill requirement (Mensah et al., 2015). MPPDME (2017) explains the mining sector has had weaknesses in the management of the implementation of the plans for guidance and support for small mining. According to Siegel and Veiga (as cited from Rosales, 2019), formalization in this context refers to creating provisions in state legislation that can incorporate ASM, allowing for proper regulation which can allow for mitigation of environmental and health impacts of the activity. Even when the participation of the Bolivarian National Armed Force is preponderant in the issue of the OMA institutionalism such as nowadays they are the responsible for safeguarding, protecting and maintaining harmony in the sector.

In terms of Industrial mining in the OMA, in two years since the creation of the OMA, senior officials stress that despite the interest shown by companies, the government has signed agreements with local mining organizations (interviews with Victor Cano, 2018; and Franklin Ramirez, 2019). In none of the cases where they have been signed compromise letters or where enterprises have been consolidated mixed enterprises and signed contracts for the exploration and exploitation, there is no information of content, at present date, it is impossible to have access to this information, it is not published in any state, or media portal of communication, conditions and details of these negotiations which are unknown to the general public (PROVEA, 2016). Nevertheless, Barreto (2018) explains 16 companies have formalized agreements and four joint ventures have been created, of which only one has a visible presence in the eastern part of the Orinoco Mining Arc. The formation of joint ventures is carried out through an association between the Bolivarian Republic of Venezuela through the Venezuelan Mining Corporation (CVM), with other public or private organizations, national or international, in which the Venezuelan State has a participation between $55 \%$ and $20 \%$ of the share capital and the private participation is between $45 \%$ and $80 \%$ (MPPDME, 2018). The State grants the joint venture the right to explore, extract and process the minerals, through the Ministry of People's Power for Ecological Mining Development. 
Table 2

Private National and International companies involved in The Orinoco Mining Arc

\begin{tabular}{|l|l|l|l|}
\hline \multicolumn{1}{|c|}{ Company } & \multicolumn{1}{c|}{ Date } & \multicolumn{1}{c|}{ Country } & \multicolumn{1}{c|}{ Mineral } \\
\hline Gold Reserve & Feb 24 $4^{\text {th }} 2016$ & Canada and Venezuela & Gold \\
\hline CAMC Engineering Co. & Feb $24^{\text {th }} 2016$ & China & Coltan Area 1 \\
\hline Afiridiam & Feb $24^{\text {th }} 2016$ & Congo & Diamonds, gold and Coltan \\
\hline Barrick Gold Int. Corp. & Aug $26^{\text {th }} 2016$ & Canada and Venezuela & Gold and copper \\
\hline Yankuang Group & Feb $24^{\text {th }} 2016$ & China & Gold Area 4 \\
\hline Faox Corp & Aug $5^{\text {th }} 2016$ & Venezuela & Coltan \\
\hline Energold Drilling Corp Minerals & Aug 5th 2016 & Canada & services \\
\hline Bedeschi & Aug $26^{\text {th }} 2016$ & Italy & steel \\
\hline Guaniamo Mining Company & Aug $5^{\text {th }} 2016$ & USA & Diamonds \\
\hline
\end{tabular}

Source: Modified from https://aguayvidanoalamina.blogspot.com/2016/09/

\section{(ii) Orinoco Mining Arc Legal Framework}

By establishing regulations, the Venezuelan government has played an integral role in shaping and designing corporate environmental policies and management practices in within the mining sector, it is important to outline the stringency of the Venezuelan regulatory environment, and its impact on mining sustainable development in the country. The Current legal framework regulating mining activity in the BR Venezuela is structured as follow: The National Constitution of the Bolivarian Republic of Venezuela (CRBV); Organic Laws, Special Constitutional Laws; Presidential Decrees; Ministerial resolutions and Central Bank resolutions. Legal Framework of Orinoco Mining Arc is presented by the Ministry of People's Power for Ecological Mining Development, and represented in Table 3. Most of the activities developed in the OMA has been protected by the enactment of multiple decrees and Official Gazettes (G.O.) most of them, within the framework of the State of Exception and Economic Emergency granted by the Supreme Court of Justice in the year 2015.

In terms of Environmental legal framework, the National Constitution of the Bolivarian Republic of Venezuela (CRBV), Article 12 stablishes: "Mining and hydrocarbon deposits, any whatever its nature, existing in the national territory, under the bed of the territorial sea, in the exclusive economic zone and on the continental shelf, belong to the Republic, are goods in the public domain and, therefore, inalienable and imprescriptible". Furthermore, on Chapter IX (CRBV) "Environmental Rights" Articles 127, 128 and 129, where environmental and socio-cultural studies are established in which environmental threats are detected to be potentially affected; as well as the communities that live in it. Article $129 \mathrm{CRBV}$ establishes that any activity capable of degrading the environment must be accompanied by an environmental and sociocultural impact assessment. Likewise, in Decree 1257, dated March 13, 1996, on the Norms on Environmental Evaluation of Susceptible Activities to Degrade the Environment, the procedures on which the study will be carried out are established (MPPDME, 2017). This decree places mining and hydrocarbons in a separate item. According to PROVEA (2016), during the 159th session of the Inter-American Commission on Human Rights (IACHR), held on December 7th, 2016 in Panama City, in the context of the OMA, the Venezuelan State acknowledged that it has no still carried out the environmental impact study ordered by the National Constitution. In the same way, PROVEA, (2016) manifests there is no information in the public in any institution of the state or public that show the existence of' environmental impact assessment for OMA implementation.

Furthermore, according to the Organic Environment Law and the Criminal Law on the Environment, refers to the need to carry out the environmental and sociocultural impact studies in all activities capable of degrading the environment, necessary to grant the corresponding permits. Convention 169 of the ILO, provides for prior, free and informed consultation of indigenous peoples when taking advantage of natural resources in indigenous habitats.

Several National Plans have been launched in the regulations of the Orinoco Ming Arc, the most recent, announced on 2019, when the President of the Republic announced the creation of the Mining Sector Plan 2019-2025, which includes an investment and technology plan to convert Venezuela into a mining power. On the basis of alliances with national and international companies and with which it is intended to generate revenues to the Republic for at least 33 billion euros, thanks to the exploration and exploitation of 13 minerals, including gold, diamond, nickel, bauxite, feldspar, phosphate, iron, among others, allowing the relief of the Venezuelan economy (Reyes, 2019). The National Mining Sector Plan 2019-2025 aims to produce 80 tons of gold per year. With this National Plan, the Government has set a goal to recover 100 percent of the country's mining companies, for which they will be formed 50 medium and 
large mining alliances (MPPC, 2019). A deepening of rentism and extractivism has also been pointed out in the protests, now with a greater incidence of transnational mining corporations. According to Lander (2016) and Arsel, et al, (2016) the OMA decree express a strategic decision to deepen extractives and accentuate logic rentier.

Table 3

Legal framework of Strategic Minerals in Venezuela

\begin{tabular}{|c|c|l|}
\hline Instrument & Issue Date & \multicolumn{1}{c|}{ Implication } \\
\hline $\begin{array}{c}\text { Organic Law. } \\
\text { Official gazette 6210. }\end{array}$ & Dec $30^{\text {th. } 2015}$ & $\begin{array}{l}\text { It is reserved to the State the activities of exploitation } \\
\text { of gold and other strategic minerals }\end{array}$ \\
\hline $\begin{array}{c}\text { National decree } \\
\text { No. 2412 }\end{array}$ & Aug $5^{\text {th }} 2016$ & $\begin{array}{l}\text { the use, possession, storage and transport of mercury } \\
\text { is prohibited }\end{array}$ \\
\cline { 3 - 3 } & $\begin{array}{l}\text { Coltan, gold, silver are declared as strategic elements } \\
\text { for exploration and extraction. }\end{array}$ \\
\hline $\begin{array}{c}\text { National decree } \\
\text { No. 2781 }\end{array}$ & March $27^{\text {th. } 2017}$ & $\begin{array}{l}\text { Diamond is declared as strategic elements for } \\
\text { exploration and extraction. }\end{array}$ \\
\hline $\begin{array}{c}\text { National decree } \\
\text { No 2782 }\end{array}$ & March 27 $7^{\text {th. } 2017}$ & $\begin{array}{l}\text { Copper is declared as strategic element for } \\
\text { exploration and extraction. }\end{array}$ \\
\hline $\begin{array}{c}\text { National decree } \\
\text { No 2783 }\end{array}$ & March 27 th. 2017 & $\begin{array}{l}\text { Silver is declared as strategic elements for } \\
\text { exploration and extraction. }\end{array}$ \\
\hline $\begin{array}{c}\text { National decree } \\
\text { No 3188 }\end{array}$ & Dec $6^{\text {th } 2017}$ & $\begin{array}{l}\text { 23 areas in Bolivar State are declared for mining } \\
\text { and eco socialist use. }\end{array}$ \\
\hline
\end{tabular}

Source: Modified from MPPDME, 2018

\section{(iii) Orinoco Mining Arc Environmental Impacts}

Carrere (2004) explains, mining activities include various stages, each of which entails particular environmental impacts. In a broad sense, these stages would be: Exploration and exploration of deposits, Development and preparation of mines, Exploitation of mines, and Treatment of minerals obtained in respective facilities with the aim of obtaining marketable products. In the exploration phase, some of the activities with Environmental impacts are the preparation of access roads; topographic and geological mappings; assembly of camps and facilities; auxiliary; geophysical work; hydrogeological research; trenching and reconnaissance wells sampling. During the exploitation phase, the impacts that occur are depending on the method used. Many Authors explain the environmental impacts generated by mining activities, the classification of these impacts responds to different criteria, where, Biotic and Abiotic Medium affectation is one of them. Direct and indirect impacts is the second one. Regarding, mining environmental impacts, Gold (2003) explains, the forest and mining use impacts on soils, hydrography, microclimate, vegetation, fauna, human communities and biological diversity in general; medicinal plants are among the resources most valuable in the forest.

Table 4

Associated Environmental Impacts to the exploitation of the OMA

\begin{tabular}{|c|c|}
\hline \multicolumn{2}{|r|}{ Abiotic Medium } \\
\hline 1 & Erosion and / or destruction of soils. \\
\hline 2 & Deviations, elimination and obstruction of water courses (Hydrography) \\
\hline 3 & Increase in sediment load in surface waters. \\
\hline 4 & Pollution, derived from the small scale mining, which will be stimulated by the OMA project. \\
\hline 5 & $\begin{array}{l}\text { Soil and water pollution for solid and liquid waste, dangerous and non-dangerous: Black } \\
\text { waters, Fuels, oils, Mercury and Cyanide. }\end{array}$ \\
\hline 6 & Eutrophication of water bodies \\
\hline 7 & $\begin{array}{l}\text { Superficial Watershed involvement of strategic importance for the country like the Caroni } \\
\text { River Basin and Caura River Basin. }\end{array}$ \\
\hline
\end{tabular}




\begin{tabular}{|c|c|}
\hline 8 & Alteration of the topography \\
\hline 9 & Destruction of scenic resources. \\
\hline 10 & Discharge of acid drains to water and soil courses, coming from the "tails", lagoons, \\
\hline 11 & $\begin{array}{l}\text { Risk of breaking dams with contaminated sludge (mercury, cyanide) in the case of large open } \\
\text { pit mining and its consequences on water resources, soil, wildlife. }\end{array}$ \\
\hline & Biotic Medium \\
\hline 1 & $\begin{array}{l}\text { Deforestation and the habitat affectation of wildlife, hydrological cycle and the process of CO2 } \\
\text { sequestration, of vital importance to mitigate climate change and global warming. }\end{array}$ \\
\hline 2 & Loss of resources from biodiversity \\
\hline 3 & Destruction and / or habitat fragmentation \\
\hline 4 & Wildlife Migration. Decrease in wildlife populations \\
\hline 5 & Affectation of ABRAE, in National parks Natural Monuments and Forest Reserves. \\
\hline 6 & Impacts on the Orinoco delta, as last receiving ecosystem of sediments and contaminants. \\
\hline 7 & Wildfire occurrence of vegetation \\
\hline 8 & $\begin{array}{l}\text { Toxicity to aquatic organisms (plankton) and ichthyofaunal involvement: turbidity of the } \\
\text { waters, death of fish high content of suspended solids and by dangerous pollutants. }\end{array}$ \\
\hline
\end{tabular}

Source: Modified from: Garcia, 2018

\section{Deforestation. Climate Change Affectation}

The Mining Belt includes approximately $20 \%(68,737 \mathrm{~km} 2)$ of all forested areas south of the Orinoco $(350,670 \mathrm{~km} 2)$; forests cover $64 \%$ of its surface. It is estimated that, together with oil exploration, mining threatens $38 \%$ of the last extensions of primary forests in the world (Carrere, 2004). In this area deforestation has increased exponentially in the 2000-2015 period, partly because of the intensification of human activities north of the Bolivar state, a mining focus of gold, diamond, iron and coltan, among other metals and minerals. A large part of these activities are directly or indirectly related to the increase in practices of informal gold mining, which affect protected areas and indigenous territories (LACA, 2018). An analysis of Landsat images carried out by NASA estimates in 1.058 square kilometers, the extension of deforested forests in the mining municipalities of the Bolivar State between 2001 and 2014. (Barreto, 2018)

These facts represent a contribution to the aggravation of the problem of climate change, given that deforestation of the forests of this region simultaneously implies an increase in the emanation of greenhouse gases and a reduction in the capacity of said forests to absorb and retain these gases. Venezuela's contribution to climate change belongs to deforestation on 20\% (Explora, 2018). In forest areas, the only deforestation of the soils with the consequent elimination of vegetation, more vast in the case of open pit mines, has short, medium and long term impacts. Explora (2018) reported the loss of forest mass in Cuyuní river basins and lower Caroní river basin, located in these areas, for the period 2000- 2013 represents $50 \%$ of all forest mass loss in time.

Deforestation not only affects the habitat of hundreds of endemic species (many brought to extinction), but the maintenance of a constant flow of water from forests to other ecosystems and urban centers. The deforestation of the primary forests causes a fast and fluid runoff of the waters coming from the rains, aggravating the floods in the periods of rain because the soil cannot contain water as it does in the presence of forested masses (Carrere, 2004). Fearnside, (1990), reported that environmental destruction in Amazonia takes many forms, such as deforestation, loss of animal and plant populations from the remaining forest, disturbance and pollution from mining, flooding by hydroelectric dams, and elimination of tribal peoples and their cultures. Indirect effects of mining promise to be even greater than most direct effects. Roads built to the mining areas bring in population, with subsequent deforestation (Fearnside, 1990). 


\section{Mining tools and practices in OMA}

The installed companies in the OMA are developing the activity in three scales: Great mining, medium mining and small mining. Hazardous chemicals used in different phases of metal processing, such as cyanide, concentrated acids, and alkaline compounds, while supposedly controlled, are current currency ending, in one way or another, in the system of the sewer system. Social and Environmental collateral impacts collateral that affect surrounding ecosystems, particularly aggravated forests and people (Carrere, 2004). Potential damages, which include everything from heavy metal contamination, through acid mine drainage (AMD), through pollution from noxious gases, to soil erosion, can be enormous if effective management tools and equipment are not in place (Hilson, 2000). Opencast mining technologies are being developed in gold mines such as Las Cristinas, the technique that has been proposed involves a conventional processing circuit of gravitational concentration and carbon leaching which includes the use of cyanide.

\section{Rivers Silt Load}

Large rivers and extensive areas of dense vegetation are the hallmarks of the Amazon region. In the foreground the Macagua dam: together with another Three: Guri, Caruachi, and Tocoma, also along the Caroní River which provides the most important freshwater reserves of the country and generating of $60 \%$ of the hydro power that feeds the dam of Guri and the hydroelectric complex (PROVEA, 2016). Gold mining contributes greatly to the silt load of rivers. Much of the mining is done in river beds, either by dredging alluvium from the river bottom or by panning it from the banks. The river water is often a milky color from the silt load far below the mining sites themselves. As with other minerals, roadbuilding spurred by gold strikes sets in motion the process of invasion and deforestation of the affected areas (Fearnside, 1990).

\section{Impacts on Areas under special administration}

The surface of the Bolivar state is almost entirely under legal figures of special administration, covering $22.5 \%$ of the area of the region (Explora, 2018) from here the importance of the Bolivar state for the country (INE, 2011). In this state, 7 million 262 thousand 358 hectares are Areas under regime of' special administration (ABRAE in Spanish) given its wide and incalculable biodiversity in forests, jungles, including the Imataca Forest Reserve, La Paragua and El Caura with 5 million 134 thousand hectares, natural monuments as the case of Guanay decreed on year 1991 and basins that are protected equally by environmental laws and international agreements as the Caroní Basin of 96 thousand square kilometers. In the BR Venezuela, there are eight main types of Natural Areas under Special Administration defined as: national parks, natural monuments, protected zones, woodlands, forest reserves, biosphere reserves, wildlife refuges and protected watersheds. Depending on their productive and recreational functions, most of these ABRAE would be directly affected by the OMA.

\section{Orinoco watershed Affectation}

The watersheds of the Guiana Shield contribute to the hydrological cycle, climate regulation and to maintain the flow of the Orinoco River. Forests and other natural plant communities that encompass these river basins constitute a source of oxygen and clean air for Venezuelan. The Orinoco basin is a binational basin, with an extension of 1,080,000 square kilometers. Of this $30 \%$ belongs to Colombia and $70 \%$ to Venezuela. It draws on the contribution of more than 2,500 rivers and streams, born in Colombia, has a length of 2,140 kilometers, it is the third river in the world in terms of discharge (Explora, 2018). According to AAAV, (2016), more than 40\% of the Orinoco River tax basin is located in the territory covered by the Orinoco Mining Arc. Half of the watersheds that make up the southern Orinoco partially overlap with the areas of the OMA, which, aside from the Orinoco itself, is dominated by three large watersheds: the Caura (Area 2), Caroní (Area 3) and Cuyuní (Area 4), where Las Claritas gold mine is located (Lozada, 2017). The OMA polygon includes the mouth of the Apure and Zuata rivers over the Orinoco River and the basins of the Chorro Macho, Aro, Ariza, Mato, Tacoto, Caura, Cuchivero, Cuchiverito, Guaniamo, suapure and Parguaza Rivers. These rivers define the boundaries of Areas 1, 2 and 3 of the OMA, and the northwest boundaries of the Sierra de Maigualida Natural Monument and just 5 kilometers from the Cerro de Guanay Natural Monument, declared both national monuments, according to Decree No. 1.233 of November 2nd 1990, published in the Official Extraordinary Gazette No. 4,250 of January 18th 1991.

The country's most important river systems are protected under a Special Administration Regime, of this hydrographic basins, the most intervened depending on the proportion of territory affected, would be the Caroní (20.3\%), Caura (18.7\%) and Cuyuní (10\%). within the effects on the hydrographic basins, the most direct is the contamination of rivers, lagoons, reservoirs and aquifers by the discharge 
of water with mercury and even arsenic (Explora, 2018). Gutman (2019), reported mining activity in the Orinoco River basin is causing deforestation, soil erosion and water pollution, which has direct consequences on biodiversity and ecosystem services.

All natural systems are interconnected, particularly aquatic ones. All activities that occur in the basins and throughout of the Orinoco riverbed, it will eventually affect the ecosystems found in the Delta and the zone of influence of its pen, such as marine-coastal ecosystems (Explora, 2018). The use of mercury, cyanide and other heavily polluting substances is affecting water courses in the Orinoco river basin and through it is a potential source of pollution for the Caribbean Sea. Furthermore, Villamizar et al., (2016) explains all sediments and chemicals produced by mining, would flow into the Atlantic Ocean and the Caribbean sea through the Orinoco Delta, which will cause important implications in other coastal and oceanic marine ecosystems, inside and outside Venezuela borders, reaching the region of the South Caribbean (not only venezuelan coast and oceanic islands but could reach the Netherlands Antilles) and the Eastern Caribbean (from the Lesser Antilles to Puerto Rico).

\section{Caroni Watershed Affectation}

The Caroní basin provides the most important freshwater reserves in the nation. This watershed supplies hydroelectric complex (Guri, Macagua and Caruachi) that generate $70 \%$ of the consumed energy in the country, an average of 46,650 gigawatt-hours/year for the Venezuelan electricity market, playing a fundamental role in the economic and social development of Venezuela (CVG, 2004). Furthermore, Caroni is a tributary river of Orinoco watershed, as it was said before it is equally important to note that everything that reaches the Orinoco River will affect the quality of the waters and species of the Caribbean Sea and the Atlantic. Due to the recent expansion of the Caroni Hydro Electrical Dam Complex, concessions for dredging operations have not been granted in the Caroni River. Nevertheless, illegal dredging operations have been reported in the middle Caroni River (Sandoval et al., 2006).

Figure 2

Orinoco Mining Arc Watershed Affectation

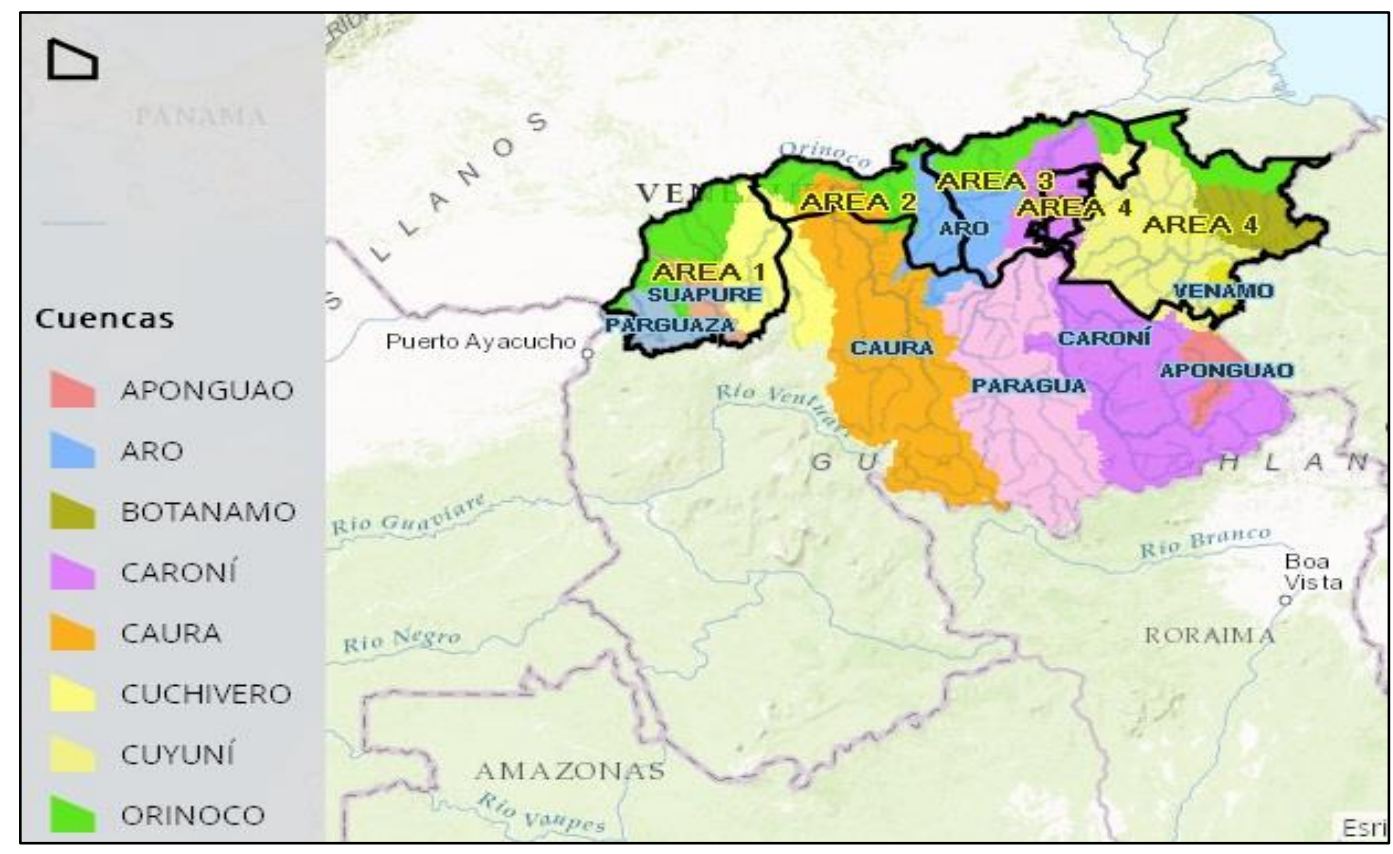

Source: Behm, (2016) 


\section{Imataca Forest Reserve Affectation:}

The Imataca Forest Reserve is located within Area 4 OMA, between the $6^{\circ} 00^{\prime}$ and $8^{\circ} 30^{`}$ North latitude and $59^{\circ} 50^{`}$ and $62^{\circ} 10^{`}$ West longitude it was created in January 1963 as an area destined to the permanent production of wood. Occupies an area of 32.032,5 square kilometers (3,200,000 ha). Located east of the Venezuelan Guiana, covers part of the Municipalities Piar, Roscio and Siphones of the Bolívar State and Casacoima and Antonio Diaz of the Delta Amacuro State; their boundaries are made up of the Orinoco River to the north; the edge of the National Park Canaima to the south; the Essequibo Territory (currently zone in claim by Venezuela) to the east and to the west, by an irregular line that runs almost parallel to the Tribal 10, which is the road axis that connects Guayana city with Tumeremo, passes through El Dorado and arrives at the border with Brazil in Santa Elena de Uairen (Padilla, 2006).

On 1997, the Ministry of Environment issued Decree 1850 to determine the territorial planning of this reserve, allowing mining in some sectors, this decree tried to solve a difficult situation with thousands of illegal miners and with private companies that the State (Ministry of Energy and Mines and Venezuelan Corporation of Guayana) had invited for the realization of the initial work of prospecting and exploration. The ban on mining in Imataca is not considered very realistic, since this activity has been developed for more than 100 years, it is dispersed in more than 3,200,000 ha of high and dense jungle, and its strict protection by operation is almost impossible by the Armed Forces (Lozada \& Arends, 2000). The environmental services provided by the Imataca Forest Reserve are described: biological diversity, relevance in soil and water protection, capacity as a regulator of gases and climate, and imposing scenic beauties. Based on the relevance of this reserve for the regulation of regional and global climate, proposals have been submitted to declare a large part of the Imataca Forest Reserve as Imataca National Park, Imataca Biosphere Reserve or a more restrictive figure that allows to preserve and preserve those valuable ecosystems (Gold, 2003).

Lozada \& Arends, (2000), describes the types of mining developed in Imataca and their environmental impacts during exploration and exploitation phases, furthermore reports the main impact of mining in Imataca Forest reserve is mercury pollution. Mercury pollution is rapidly becoming a public health crisis in Amazonia. Use of mercury to amalgamate the fine gold particles in the extraction process (Fearnside, 1990), mercury is used by small and medium miners to separate the gold from the sand (ground or ground stone) and, in the process, a part of that metal evaporates or goes to water and soil. Carrero, (2004) explains that the OMA represents a frontal legalization of mining, enabling prospecting, exploration, exploitation, processing, transformation and transport of metallic and non-metallic minerals, in an area that due to its high ecological fragility, acidity of its soils, and its very low capacity for regeneration once intervened is in the category of "forests in danger of disappearing". Mansutti-Rodriguez, (2000) adds that the north of Imataca Forest reserve, together with the northern sector of the Caura Forest Reserve are considered by the Joint Research Center of European Commission as hot spots of deforestation in the humid tropics.

Furthermore, reported Artisanal Gold mining practices in La Draga Gorge (in Spanish), in the Imataca Forest Reserve have reported to generate large amount of sediments that drastically clog the hydrographic network where the deliberate obstruction of the springs causes the death of surrounding forests by permanent waterlogging (Montes, 2016). Finally, Lozada \& Arends (2000), emphasizes that this forest reserve does not belong to the Caroní River Basin, which has been widely manipulated by public opinion.

\section{El Caura Forest Reserve Affectation}

Within the territory that the project of the Orinoco Mining Arch, there are 6,296 $\mathrm{km}^{2}$ of the El Caura Forest Reserve, which was considered until the end of the last century as the basin hydrographic more pristine (intact) and possibly the largest in the tropics (Explora, 2018)

\section{Canaima National Park National affectation}

The four national parks in the Venezuelan Amazon cover an area of approximately 57.190 square kilometers. All were established by different presidential decrees and now belong to an administrative unit of the National Parks Institute (INPARQUES in Spanish) called the South National Parks Sub system. Canaima is the second largest national park of the 43 that exist in Venezuela. It occupies an area of 30,000 square kilometers. Created in 1962 and declared a World Heritage Site by UNESCO in 1994. Canaima National Park, is an important tourist destination, so it serves as a basis for the development of economic activities of local communities. This National Park is a wildlife refuge of the Arrau Turtle and Orinoco delta Biosphere Reserve (Explora, 2018). The 2015 Annual Report of the Office of the Comptroller General of the Republic recorded the results of the inspection carried out on 14 May 2014 in the Indigenous 
Community of Campo Alegre (coordinates N 04 $45^{\prime} 80^{\prime \prime}$ and W 61 $\left.12^{\prime} 00^{\prime \prime}\right)$, located in the eastern sector of the Canaima National Park: "... the practice of mining activity was evident in the vicinity of the Kukenan River, carried out with the use of petrol pump equipment and conveyor belts for the extraction of gold (...) pollution damage to the main water source of Bolivar state and part of Venezuela's territory, as well as the ecosystem of Canaima National Park".

\section{Natural monuments Affectation}

Natural monuments are generally intended to provide protection to small areas containing special or unique natural features of very high conservational value, such as caves, waterfalls, and isolated mountains. There are currently 29 natural monuments in the Venezuelan Guayana including 17 in the Bolivar State, but none of them yet have management plans prepared by INPARQUES, the government agency responsible for their supervision. About Biosphere reserves, the use of this legal figure in the conservation policy of Venezuela is very recent. The 'Alto Orinoco-Casiquiare' Biosphere Reserve was one of the first two biosphere reserves created by presidential decree in June 1991. Both were designed to offer protection to two important Amerindian groups and their traditional homelands, one at the mouth of the Orinoco River in Estado Delta Amacuro, the other at its headwaters in Amazonas State.

Figure 3

Orinoco Mining Arc Protected Areas

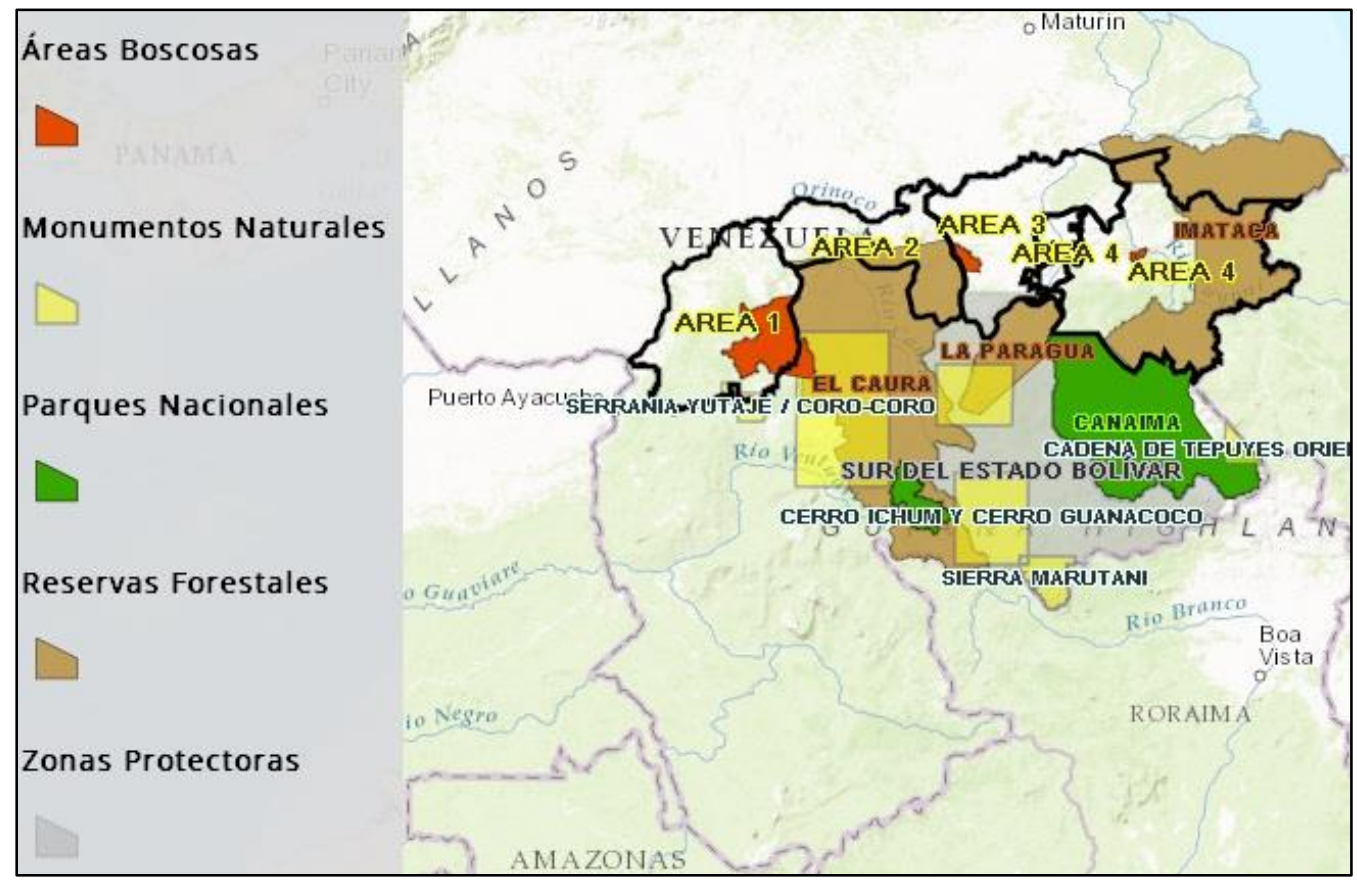

Source: Behm, (2016)

\section{Biodiversity resource loss}

Yranzo (2016), about fauna threatened by the OMA project, characterized BR Venezuela as a megadiverse country given the great variety of species found in it, considered 6th country in Latin America with greater variety of life and 10th worldwide, the fourth largest country in the world number of amphibian species, the sixth in birds, the eighth in mammals and ninth in reptiles: 386 species of mammals; 1463 bird species, 377 reptile species, 640 species of amphibian, 1860 species of fish, 15,636 plant species (Explora, 2018), indicating the area that presents the greatest diversity of fauna is that where the Orinoco Mining Arc is located, which would be severely affected by the proposed mining exploitation. In this regard, according to the Red Book of Venezuelan Fauna, 23 species of mammals that inhabit this region are threatened with extinction. Species like the Orinoco manatee (Trichechus manatus), the giant armadillo (Priodontes maximus), the major sucker bat (Thyroptera lavali) and the southern spider monkey (Ateles belzebuth) are almost exclusive 
inhabitants of the Amazon and Venezuelan Guiana, where the main threat is habitat loss (Explora, 2018). Furthermore, LACA (2018) reported there is evidence of these toxins bioaccumulation in fish and shellfish sampled kilometers away from the nearest mine in the catchment area of the river Orinoco pen.

\section{(iv) Policies for sustainable development}

Sustainable development is a term introduced in 1987, when the World Commission on Environment and Development (WCED), published a report entitled "Our common future". This document also known as the "Brundtland Report" is often cited for its definition of sustainable development: "Development that meets the needs of the present without compromising the ability of future generations to meet their own needs." Three fundamental components to sustainable development are described: environmental protection, economic growth and social equity. Mining has a commitment priority with sustainable development, in its three dimensions: Environmental, social and economic.

About Mining and sustainable development, Hilson (2000) explains since a wide range of natural, cultural, and socioeconomic resources can be potentially negatively impacted by mining activity, there are a great number of opportunities for individual mines to contribute to sustainable development, although in ways that much of the literature fails to identify, by preventing significant environmental problems, adopting proactive environmental standards, and encouraging improved performance, the mining industry can contribute greatly to sustainable development. Considering the importance of economic development of the country, the concept of sustainable development focused attention on finding strategies to promote economic and social advancement in ways that avoid environmental degradation. Experts have attempted to outline how sustainable development applies to mining activities and mineral-based economies.

MPPDEM (2018) states that the mission of the ministry is to guarantee the sovereignty of the Venezuelan State over the responsible, efficient and sustainable use of non-renewable mineral resources, with minimal impact on the environment and its biological diversity, thanks to the efficient use of science and technology, with balanced participation of all the actors linked to mining activity

The Venezuelan government has taken concrete steps to address some of the problems on how mining activity should be ordered to contribute to sustainable development. Environmental responsibility has been set by the government by several measures and actions considered in the National Regulations which include: (i) Remediation and recovery of areas degraded by irresponsible mining with the support of research institutes in Venezuela and other countries; (ii) Fulfilling of environmental laws and prohibition on the use of mercury, as one of the metals susceptible to causing greater environmental damage and risk to the human health and other organisms. Research lines are being developed on techniques of remediation and recovery of areas degraded by the liabilities of the irresponsible inherited mining, ranging from bioremediation to the subsequent use that must have the areas once recovered (MPPDME,2017). The Government issued Decree No. 2412, published in Official Gazette No. 40960 dated August 5th, 2016, regarding the prohibition of the use of mercury $(\mathrm{Hg})$. At the same time, several diagnoses are being made to determine possible areas contaminated by mercury, in order to formulate the corresponding corrective measures.

\section{CONCLUSION AND RECOMENDATIONS}

\section{Conclusions}

The OMA project is progressing without the corresponding environmental and sociocultural impact studies. Such Guayan territory of high mining interest overlaps total or partially to several areas under special administration: Canaima National Park, Three Forest Reserves (Caura, Imataca and Paragua), one protected zone, one Natural Monument; hydric reserves and the Caroni Watershed. These ABRAE are considered of very high ecological value, of biodiversity and strategic environmental services, where any activity likely to cause damage to ecosystems must be previously accompanied by environmental and socio- cultural impact studies where there should be commitment by both government and industry to environmental protection and extended socioeconomic responsibility, integrating the needs of the environment, economy, and society, producing a solution that represents the 'best fit' for all parties impacted by decisions. Most of the consulted literature in this research is focused on the illegal mining activities and the related environmental impacts, where no official report exist about the industrial mining or transnational mining industries activities. Although MPPDME (2018) states one of the main premises in the mining activity in the country is the use of technologies of low environmental impact, through the balance of ecology and economy in all mining projects, the evidence shows the opposite. 
Explora (2018) reports depending on a set of conditions, strategies that minimize impacts can be devised or that facilitate the recovery of exploited areas, but in no way can it be said that there won't be negative impacts or that there are appropriate recovery strategies for all altered systems, or that in all cases, a restoration of the pre-existing natural system will be achieved. There is enough evidence to assume that the aforementioned impacts will be magnified if the decree (OMA) continues being implemented without rigorous control and management. In addition, these impacts can transcend the borders of Venezuela far beyond the area of influence of the Orinoco river, affecting the southwestern Caribbean, thus becoming a threat of regional reach.

Both the government and the mining industry should address mining sustainable development through policy-making, by establishing regulations and environmental legislation that can be achieved through improved environmental management practices and socioeconomic performance. Furthermore, strict compliance with our environmental regulations must be done. Early efforts are required to stablish in this sector to prevent irreversible environmental damage. The south of the Orinoco is a region with great potential to help the development of the country, not only for the wealth of resources found there but for the high capacity of environmental service generation. However, to be able to properly exploit this potential, it is necessary to follow principles of sustainable development in order to ensure that wealth and benefits that society obtains from environmental services that this region offers, continue to be available for future generations.

Innovation is an essential part of any industry including mining companies. The ability to innovate and use new technologies generates new knowledge. In this sense, encourage research and technological development, allocating greater resources to these activities. They must be part of the development policies of the governments. Clean technologies in the small gold mining sector, shows the need for a comprehensive approach that includes legal, socio-economic aspects, technical and environmental for a successful implementation of measures environmentally clean and to afford the challenge of solving the growing needs of society in a sustainable manner, without causing depletion or degradation of natural and energy resources, while also avoiding increasing social inequalities.

Nowadays, several mining technologies can be developed by companies which develop good environmental management, particularly when stakeholders want to attack the problems in causes that generate them and not in the final consequences. The study and promotion of a clean Production Agreement between actors in the national mining sector with the commitment to comply with management integral associated with mining development; presentation and application of clean technologies; practical tools to address the environmental and safety issue mining; training in the field of clean technologies; pilot plans of clean technology assessment. Furthermore, the decisions related to this National project should be taken based on the best available scientific information emphasizing the inclusion of alternatives based on sustainable development and best practices.

\section{Recommendations}

Nowadays, when global environmental awareness has increased due to the dramatic loss of thousands of species and ecosystems in the world, and to massive mobilization of people who demand respect for nature and the signing of International treaties to prevent climate change, desertification, loss of biological diversity, disappearance of forests and water sources, in the BR Venezuela, the commitment to deepen the protection of the forests of Venezuelan Guiana is on debate. The authors consider the environmental assessments should be carry out and be transparent an available to the general public. According to the Venezuelan regulations, each environmental impact study is specific and must comply with the provisions of the Ministry of Popular Power for Eco socialism and water (MINEA) in the terms of reference. These are required within the legal framework of the project which directly affect the ecosystems of world interest, since the Orinoco Mining Arc is part of the Amazon, also to analyze the cost of the ecosystem loss ecosystem and the environmental liabilities that derive from it. Recommendations for future research include the sustainable policy making development in the region. Important contributions could be made to mining sustainable development through training area, where nationals and foreign scientists can make an important improvement. Although universities and research institutions in tropical areas of South America are rapidly growing stronger, they are still pitifully small when compared to the magnitude of the challenge of devising sustainable forms of development for Amazonia's vast, complex, and poorly-studied ecosystems (Fearnside, 1990).

In this regard, actors should assess whether the economic income resulting from the extraction of gold, coltan or diamond are really more valuable than all services of the ecosystems that these watersheds offer, and equally, if the country have the capacity to response to a potential environmental disaster. In the debate on the environmental impacts of the Orinoco Mining Arc is to generate a comprehensive study and discussion on environmental policy that allows to promote a process of awareness and defense of environmental rights to strengthen movements in the defense of social rights and conquests recognized in the year 1999 National 
Constitution of the BR Venezuela. Furthermore, we recommend to resize prospecting areas, particularly those superimposed on ABRAE and indigenous territories.

Protection is needed in fact of natural forest reserves that are now only declared on paper. Despite the tremendous need for change, BR Venezuela has made great advances in protecting examples of its natural ecosystems and incorporating environmental factors into development procedures. Eradication of artisanal mining practices that inflict high environmental damage, artisanal mining and of medium scale, those that produce greater negative impacts due to the characteristics of their operation and the difficulty of monitoring these mines. Resizing of industrial gold mining plans and application of non-polluting technologies, carry out socio-environmental measures compensatory to impacts inevitable negatives of gold mining on an industrial scale.

The legal and legislative advances in protecting the environment must be further fortified by building a corps of qualified people to carry them out and a tradition of serious consideration of the environment in planning development, especially in the early phases of project formulation before major developments become irreversible. Implement the regulations of law recognized by the different countries to protect the environment, through mitigation and remediation of impacts. To prevent the deficient control of small-scale mining by state institutions, which generates a social break in health, safety, and other economic activities and, in general, a deterioration in the life quality of its inhabitants.

Finally, the sustainable development of the country should be seen as an integral issue and not as an exploitation of isolated resources. The regional planning process is due guide to consider the territory as a fundamental element where a model of sustainable development. This requires an interdisciplinary approach in the design of public policies in Venezuela, where processes of spatial organization allows balanced development according to the environmental, economic and social possibilities of the region. According to the scenic beauty and considering the implementation of economic diversity, if adequate management plans are implemented and well-coordinated between the various authorities and private enterprises, touristic economic activity may well become one of the main income sources for the local populations and stimulate the building of a basic infrastructure able to raise significantly their living conditions on a longterm perspective (Huber, 2001).

\section{REFERENCES}

[1] AAAV, 2016. Pronunciamiento de la AAAV sobre el decreto 2248 y el Arco Minero del Orinoco (In Spanish). [online] Available at: https://www.aporrea.org/ddhh/ [Accessed on Dec 20 $0^{\text {th }}$ 2019]

[2] Arsel, M., Hogenboom, B., \& Pellegrini, L. (2016). The extractive imperative in Latin America. Extractive Industries and Society, 3(4), 880-887. https://doi.org/10.1016/j.exis.2016.10.014

[3] Barreto, J. (2018) Arco Minero del Orinoco, Crimen, Corrupcion y Cianuro. [online]. Available at: https://www.arcominerodelorinoco.com/. Accessed on 15/12/2019. [Accessed on Nov 16 ${ }^{\text {th }} 2019$ ]

[4] BCV, 2019. Estadisticas Producto Interno Bruto (2019). [online]. Available at http://www.bcv.org.ve/estadisticas/productointerno-bruto. [Accessed on Dec 15 ${ }^{\text {th }}$ 2019]

[5] Behm V. 2016. Arco Minero En El Estado Bolívar. Venezuela. ArcGIS (In spanish). [online]. Available at: https://www.arcgis.com/home/item. html?id=1caf35c6c7d34945888b13ca07bd95b0. [Accessed on Nov 11 ${ }^{\text {th }} 2019$ ]

[6] Blanco F., Agudo E. (2018). Orinoco Mining Arc and the Caribbean: Possible impacts over marine ecological processes (ppt) Latin America and Caribbean Congress for conservation biology. [online] Available at: https://lacccb2018.org/orinoco-mining-arc. [Accessed on Dec $5^{\text {th }}$ 2019].

[7] Bolivariana de Venezuela, Repúblic (2011). Decree N 8413, Official Gazette No. 39.759. with Rank Value and Strength of Organic Law, which reserves the State the activities of exploration and exploitation of gold.. National Assembly, Caracas, Venezuela.

[8] Bolivariana de Venezuela, Repúblic (2015). Decree No. 2.165 Official Gazette No. 6.210 dated Dec 30 2015 , through which the Decree with the Rank, Value and Force of Organic Law that Reserves to the State the Exploration and Exploitation Activities of Gold and other Strategic Minerals is dictated. National Assembly, Caracas, Venezuela.

[9] Bolivariana de Venezuela, Repúblic, (2016). Decree $N^{\circ} 2.248$, published in Official Gazette No 40.855, through which the National Strategic Development Zone "Arco Minero del Orinoco" is created. Caracas Venezuela.

[10] Bolivariana de Venezuela, Republic (2016) Decree No. 2.412, published in Official Gazette No. 40960 dated August 5th, 2016, regarding the prohibition of the use of mercury $(\mathrm{Hg})$. National Assembly, Caracas, Venezuela. 
[11] Carrere, R. (2004). Minería: Impactos sociales y ambientales. [online]. Available at http://www.wrm.org.uy/oldsite/deforestacion/mineria/texto.pdf. [Accessed on Dec $5^{\text {th }} 2019$ ]

[12] CVG 2004. Corporación Venezolana de Guayana-Electrificación del Caroní CA. La Cuenca del Río Caroní: Una Visión en Cifras. Caracas, Venezuela: CVG-EDELCA, 2004, 1-243.

[13] Explora, 2018. Una Mirada al Soberano de Sur, entendiendo las implicaciones del Arco Minero (In spanish). 1-18 [online]. Available at https://issuu.com/grupoexplora/docs/1.-_edici_n_amo_final_30_mayo_2018 [Accessed on Dec 10 ${ }^{\text {th }} 2019$ ]

[14] Fearnside, P. M. (1990). Environmental Destruction in the Brazilian Amazon. The Future of Amazonia, $179-225$. https://doi.org/10.1007/978-1-349-21068-8_8

[15] Carcia, P., 2018. Impacto Ambiental del arco Minero del Orinoco (In spanish). UCV Oct. 25th 2018. [online]. Available at: http://acading.org.ve/info/comunicacion/pubdocs/Foro_Arco_Minero/PRESENTACION_OMA.pdf. [Accessed on Nov10 ${ }^{\text {th }}$ 2019]

[16] Gold, B. (2003). Conservación La reserva forestal de Imataca (Venezuela ): Un bosque insustituible en peligro de desaparecer (in spanish), 152-155.

[17] Gutman, D (2019). La minería sin control pone en riesgo la cuenca del río Orinoco (In Spanish). [online]. Available at: http://www.ipsnoticias.net/2018/07/la-mineria-sin-control-pone-riesgo-la-cuenca-del-rio-orinoco/. [Accessed on Nov $7^{\text {th }}$ 2019]

[18] Hilson, G. (2000). Sustainable development policies in Canada's mining sector: An overview of government and industry efforts. Environmental Science and Policy, 3(4), 201-211. https://doi.org/10.1016/S1462-9011(00)00086-1

[19] Huber, O. (2001). Conservation and environmental concerns in the Venezuelan Amazon, 1627-1643.

[20] INE (2011), National Insitute of Statistic Bolivariana de Venezuela. (2011), Informe Geoambiental Bolivar. (in Spanish). [online]. Available at: http://www.ine.gov.ve/documentos/Ambiental/PrincIndicadores/pdf/Informe_Geoambiental_Bolivar.pdf. [Accessed on Dec $\left.15^{\text {th }} 2019\right]$

[21] LACA. (2018). Declaración del LACCCB 2018. Implicaciones regionales del Arco Minero del Orinoco, 4. [online]. Available at: http://www.conbio.org info. [Accessed on Dec 8 ${ }^{\text {th }}$ 2019]

[22] Lander, E. (2016). La implosión de la Venezuela rentista. Rosa Luxemburg, 1-23. [online]. Available at http://www.rosalux.org.ec/es/52-actividades/eventos-lo-mas-reciente/918-la-implosión-de-la-venezuela-rentista.html. [Accessed on Dec $5^{\text {th }} 2019$ ]

[23] Lozada, J., \& Arends, E. (2000). Aspectos ambientales de los diferentes tipos de minería de oro, desarrollados en la reserva forestal Imataca (In spanish). Revista Forestal Latino-Americana, 15(27), 81-99.

[24] Lozada, José. (2017). Mitos y Leyendas Relacionados con el Arco Minero En La Guayana Venezolana (In spanish). 9. $478-485$

[25] Mansutti-rodriguez, A. (2000). Diagnóstico de los conflictos socio ambientales en Imataca: Líneas estratégicas de un programa para el resgüardo y la consolidación de los asentamientos humanos ubicados en la Rese..., (May). https://doi.org/10.13140/RG.2.2.20383.46244. Accessed on 12/10/2019

[26] Martiz, M. (2019). La Sangrienta fiebre del Oro (In Spanish). [online]. Available at: https://static1.squarespace.com/static/59ece4196f4ca3771ef086ff/t/5d07f4971649cb0001cabe25/1560802476848/Mineria_Transp arencia.pdf. [Accessed on Nov 25 ${ }^{\text {th }}$ 2019]

[27] Mensah, A. K., Owusu, O., Kissi, E., Mensah, A. K., Mahiri, I. O., Mireku, O. D., ... Kissi, E. A. (2015). Environmental Impacts of Mining: A Study of Mining Communities in Ghana A quantitative Assessment of the Mass Cocoa Spraying Exercise (CODAPEC) in Ghana View project Effects of Biochar and Compost Application on Some Soil Properties, Growth and Yield of M. Applied Ecology and Environmental Sciences, 3(3), 81-94. https://doi.org/10.12691/aees-3-3-3

[28] MPPDME. (2017) Ministerio del Poder Popular para Desarrollo Minero Ecológico,(In Spanish). Por Una Minería Responsable. Caracas, Venezuela. [online]. Available at: http://www.desarrollominero.gob.ve/wpcontent/uploads/2018/04/Porunamineriaresponsable_Ijornadastecnologicasdeloro.pdf. [Accessed on Dec $9^{\text {th }}$ 2019]

[29] MPPDME. (2018) Ministry of People's Power for Ecological Mining Development. Responsible Mining in Venezuela. [online]. Available at: http://desarrollominero.gob.ve/catalogo-minero-venezolano/. [Accessed on Nov 15 2019 ]

[30] MPPC, (2019) Ministerio del Poder Popular para las Comunas y los Movimientos Sociales, Presidente Maduro Aprobó El Plan Sectorial Minero 2019-2025 (In Spanish). [online]. Rerieved from: https://www.mpcomunas.gob.ve/2019/06/06/presidentemaduro-aprobo-el-plan-sectorial-minero-2019-2025/. [Accessed on Dec $7^{\text {th }} 2019$ ] 
[31] Montes, G. (2016) Problemas Ambientales y socio culturales vinculados a la Mineria (In spanish). [online]. Available at: https://www.aporrea.org/media/2016/10/investigacin_gustavo_montes_2da_parte.pdf. [Accessed on Nov 5 ${ }^{\text {th }} 2019$ ]

[32] Odell, S. D., Bebbington, A., \& Frey, K. E. (2018). Mining and climate change: A review and framework for analysis. Extractive Industries and Society, 5(1), 201-214. https://doi.org/10.1016/j.exis.2017.12.004

[33] OPEC. Annual Statistical Bulletin (2019). [online]. Available at: https://www.opec.org/opec_web/en/data_graphs/330.htm. [Accessed on Nov 18 ${ }^{\text {th }}$ 2019]

[34] Padilla, A. (2006). Desarrollo sostenible de la reserva forestal Imataca ¿utopía o realidad? (In spanish), 53-80.(January 2003). https://www.researchgate.net/publication/228762776.

[35] PROVEA (2016). Derechos humanos en el contexto del proyecto "Arco Minero del Orinoco" en Venezuela (In spanish). [online]. Available at: https://www.derechos.org.ve/web/wp-content/uploads/DDHH-en-el-contexto-del-OMA-en-Venezuela.pdf. [Accessed on Nov 18th 2019].

[36] PROVEA (2016). Estado reconoce en CIDH que no ha realizado estudio de impacto ambiental para Arco Minero (In spanish) [online] Available at: https://www.derechos.org.ve/actualidad/estado-reconoce-en-cidh-que-no-ha-realizado-estudio-de-impactoambiental-para-arco-minero [Accessed on Nov 18th 2019].

[37] Reyes, K. (2019). En que consiste el Plan de Mineria 2019 en Venezuela, (In spanish) [online]. Available at https://radiohrn.hn/enque-consiste-el-plan-de-mineria-2019-en-venezuela/, [Accessed on Jan 6th 2020]

[38] Rosales, A. (2017). Venezuela's Deepening Logic of Extraction. NACLA Report on the Americas, 49(2), 132-135. https://doi.org/10.1080/10714839.2017.1331794

[39] Rosales, A. (2019). Statization and denationalization dynamics in Venezuela's artisanal and small scale-large-scale mining interface. Resources Policy, 63(May), 101422. https://doi.org/10.1016/j.resourpol.2019.101422

[40] Sandoval, M. C., Veiga, M. M., Hinton, J., \& Sandner, S. (2006). Application of sustainable development concepts to an alluvial mineral extraction project in Lower Caroni River, Venezuela. Journal of Cleaner Production, 14(3-4), 415-426. https://doi.org/10.1016/j.jclepro.2004.10.007

[41] Teran-Mantovani, E. (2018). Inside and beyond the Petro-State frontiers: geography of environmental conflicts in Venezuela's Bolivarian Revolution. Sustainability Science, 13(3), 677-691. https://doi.org/10.1007/s11625-017-0520-7

[42] Villamizar E., El Souki M., Villalba L., Herrera A. T., Yranza, A., Toro M., Grillet M. E., Griffon D. \& Rodríguez D. (2016). UCV Consecuencias ambientales del Proyecto Arco Minero.(in Spanish) PROVEA. [online]. Available at: https://www.derechos.org.ve/actualidad/ucv-consecuencias-ambientales-del-proyecto-arco-minero [Accessed Nov 18 ${ }^{\text {th }} 2019$ ].

[43] Yerena, E. (2011). La guayana venezolana: sostenibilidad ambiental incierta. Mundo Nuevo, Vol., 1, N, 339-357. [online]. Available at http://www.iaeal.usb.ve/mundonuevo/revistas/MN06/MN_06(10).pdf. [Accessed Nov 18 ${ }^{\text {th }} 2019$ ].

[44] Yranzo Ana (2016), Fauna amenazada por el macroproyecto Arco Minero del Orinoco, Ana Yranzo (In Spanish). [online] Available at https://www.aporrea.org/tecno/n297917.html, on Dec 29th 2019. [Accessed Dec 15 ${ }^{\text {th }} 2019$ ].

\section{AUTHORS}

First Author - Doris Daniela Rivero Rodriguez, Master Degree Candidate, Tongji University, College of Environmental Science and Engineering, Institute of Environment and Sustainable Development (IESD), Shanghai, China. Phone +86 15221394680. Email: dorisriveror@gmail.com / dorisrivero15@outlook.com.

Second Author - Ying Liu, Doctor and Professor at Tongji University, Associate Professor, College of Environmental Science and Engineering. Phone +86 13482293018. Email: liu_ying@tongji.edu.cn / liuying.tongji@gmail.com. 